\title{
Tree canopy and herb layer transpiration in three Scots pine stands with different stand structures
}

\author{
Dietmar Lüttschwager ${ }^{a^{*}}$, Steffen Rust ${ }^{\mathrm{b}}$, Monika Wulf ${ }^{\mathrm{a}}$, \\ Jacqueline Forkert ${ }^{\mathrm{b}}$, Reinhard F. Hüttl ${ }^{\mathrm{b}}$ \\ ${ }^{a}$ Center for Agricultural Landscape and Land use Research, Eberswalder Straße 84, 15374 Müncheberg, Germany \\ ${ }^{b}$ Technical University of Brandenburg, 03013 Cottbus, Germany
}

(Received 30 March 1998; accepted 25 January 1999)

\begin{abstract}
To evaluate the impact of herb layer structure on the transpiration of Scots pine ecosystems in north-eastern Germany, we measured tree canopy and herb layer transpiration in three stands. Parameters of tree hydraulic architecture were measured and their drought stress monitored. Despite striking differences in ecosystem structure, combined tree and herb layer transpiration was equal for all three sites. Transpiration rate per needle area and tree canopy transpiration were least at the site dominated by the tall grass species Calamagrostis epigeios. Pine pre-dawn water potential in the Calamagrostio-Cultopinetum sylvestris was never lower than in the Myrfillo-Cultopinetum sy/vestris, indicating that severity of competition of ground vegetation was not much different. Huber values, xylem hydraulic conductance and leaf-specific conductance of pine were least in the Calamagrostio-Cultopinetum sylvestris. Thus, pine transpiration rate might have been adjusted to lower tree hydraulic conductance and the herbaceous species used the water left by the trees. (C) Inra/Elsevier, Paris.)
\end{abstract}

canopy / herb layer / transpiration / hydraulic conductance / Scots pine

Résumé - Transpiration des arbres et de la strate herbacée dans trois peuplements de pins sylvestres de différentes structures. Dans le but d'évaluer les effets de la strate herbacée sur la transpiration d'écosystèmes de pins sylvestres en Allemagne du nord-est, la transpiration des houppiers et de la strate herbacée a été mesurée dans trois peuplements. Les paramètres de l'architecture hydraulique et le niveau de contrainte hydrique ont été mesurés. Malgré des différences importantes dans la structure de chacun de ces trois peuplements, leur transpiration totale (arbres plus herbe) était identique. Le taux de transpiration par unité de surface foliaire, ainsi que la transpiration par arbre étaient les plus faibles dans le site à dominante de Calamagrostis epigeios. Le potentiel hydrique de base dans le site à Calamagrostio-Cultopinetum sylvestris n'a jamais été inférieur à celui mesuré dans le site à $M y r t i l l o-$ Cultopinetum sylvestris, ce qui permet de conclure à un niveau de compétition entre les arbres et l'étage herbacé peu différent. Les valeurs de Huber, la conductance hydraulique du xylème, ainsi que la conductance hydraulique spécifique foliaire des pins étaient les plus faibles dans le Calamagrostio-Cultopinetum sylvestris. Ainsi, le taux de transpiration des pins semble s'ajuster pour réduire la conductance hydraulique, la ressource hydrique laissée par les arbres étant consommée par la strate herbacée. (C) Inra/Elsevier, Paris.)

couvert / strate herbacée / transpiration / conductance hydraulique / pin sylvestre

\footnotetext{
* Correspondence and reprints

dluettschwager@zalf.de
} 


\section{Introduction}

Scots pine is the dominant tree species in more than two thirds of the forests in north-eastern Germany. Site factors, especially soil $\mathrm{pH}$, nutrient and soil water availability cause important differences in the structure and species composition of these pine forests [6]. The different types of stands are characterised by the dominance of various herb species. For example, mature pine stands on podsolic soils poor in nutrients have only a sparse cover of grass species on the forest floor, whereas stands richer in nutrients have a dense cover of grasses, e.g. Brachypodium sylvaticum and Calamagrostis epigeios $[2,11,15]$. The various forest ecosystem types have markedly different rates of biomass production. Calamagrostio-Cultopineti, i.e. stands with dominance of Calamagrostis epigeios, produce 4-5 t biomass $\mathrm{ha}^{-1} \mathrm{a}^{-1}$ in the herb layer. Stands dominated by Deschampsia flexuosa, so-called Avenello-Cultopineti, reach only $0.8 \mathrm{tha}^{-1} \mathrm{a}^{-1}[11]$.

In many earlier ecosystem studies total stand transpiration could not be partitioned into the contribution of the tree canopy and the herb layer. However, this is very important in order to understand the impact of stand structures on the water balance of pine ecosystems. Some authors (e.g. [11]) assume that pine stands dominated by Calamagrostis epigeios consumed significantly more water than those dominated by Deschampsia flexu$o s a$, and therefore the pine trees were more prone to drought stress. The aim of this paper is to describe the different transpiration rates of the tree and herb layer of pine ecosystems with various structures. In particular, we want to estimate the contribution of the herb layer to the stand transpiration rate. Furthermore, we want to investigate whether a pine stand with a denser cover of grasses used more water and, as a result of competition between trees and herbs, whether the trees were more likely to suffer drought stress.

\section{Materials and methods}

\subsection{Site description}

Sites were selected to represent major pine ecosystem types of northern Germany. The stands are 45 (Taura)- to 65 (Neuglobsow and Rösa)-year-old Scots pine (Pinus sylvestris) forests, located in the former GDR. Edaphic factors and climate are very similar (table $I$ and [30]). Data of precipitation and tensions in the upper soil during the period of measurements are shown in figure 1 .

The site Rösa suffered from heavy air pollution for at least 20 years until the re-unification of Germany in 1989. In that year, needle loss was estimated at $45 \%$ [12]. Since then, trees have partially recovered [7]. In Neuglobsow, needle loss was always low (8\% in 1989 [12]). According to the forest administration the site Rösa received approximately $1000 \mathrm{~kg} \mathrm{ha}^{-1}$ of nitrogen as urea in the years 1970-1985 (unpublished).

Table I. Characteristics of the stands.

\begin{tabular}{|c|c|c|c|}
\hline $\begin{array}{l}\text { Parameter } \\
\text { Soil }\end{array}$ & $\begin{array}{c}\text { Rösa } \\
\left(12^{\circ} 26^{\prime} \text { E 51 } 1^{\circ} 38^{\prime} \mathrm{N}\right) \\
\text { Dystric Cambisol. Sand }\end{array}$ & 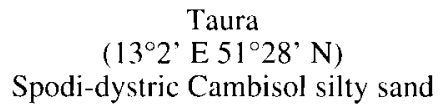 & $\begin{array}{l}\text { Neuglobsow } \\
\left(13^{\circ} 2^{\prime} \text { E } 53^{\circ} 8^{\prime} \mathrm{N}\right) \\
\text { Leptic Podzol. sand }\end{array}$ \\
\hline $\begin{array}{l}\text { Average precipitation } \\
\text { (mm/year) }\end{array}$ & 566 & 565 & 586 \\
\hline Mean temperature $\left({ }^{\circ} \mathrm{C}\right)$ & 8.87 & 8.87 & 8.18 \\
\hline Ecosystem type [11] & $\begin{array}{c}\text { Calamagrostio-Cultopinetum } \\
\text { sylvestris }\end{array}$ & $\begin{array}{c}\text { Avenello-Cultopinetum } \\
\text { sylvestris }\end{array}$ & $\begin{array}{c}\text { Myrtillo-Cultopinetum } \\
\text { sylvestris }\end{array}$ \\
\hline Former utilisation & Scots pine & Scots pine & Afforestation in second generation \\
\hline \multicolumn{4}{|l|}{ Stand structure* } \\
\hline Age (years) & 61 & 45 & 65 \\
\hline Trees $\left(1 \mathrm{ha}^{-1}\right)$ & 935 & 853 & 1043 \\
\hline Basal area $\left(\mathrm{m}^{2} \mathrm{ha}^{-1}\right)$ & 33.90 & 28.25 & 36.07 \\
\hline Average diameter $(\mathrm{cm})$ & 20.7 & 20.6 & 21.0 \\
\hline Average height (m) & 16.0 & 18.0 & 20.1 \\
\hline
\end{tabular}

* Data of the stands referring to the fenced and intensively investigated areas. 

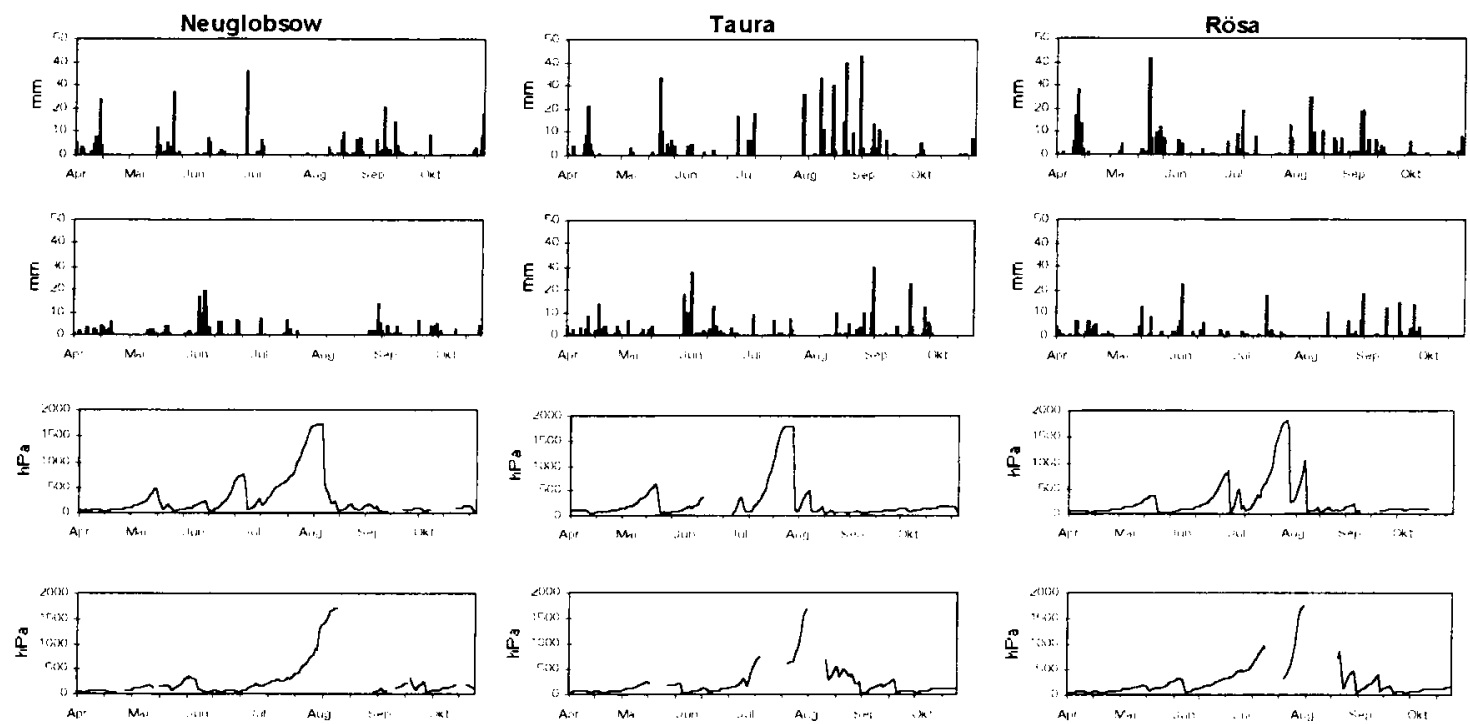

Figure 1. Precipitation and tensions in the upper soil $(20 \mathrm{~cm})$ during the vegetation periods 1994 and 1995.

\subsection{Tree biomass and leaf area index}

Five trees per stand were sampled as a stratified random sample for needle mass in September 1995. All branch diameters and the needle mass of one branch per whorl were measured. Using the close correlation of branch diameter and needle mass [14, 17], data were scaled to tree level. Specific needle area (projected) was estimated with an image analysis system (CUE-3 Image analyser, Olympus) samples being stratified for crown location, age and length. A regression of the projected needle area on sapwood area was used to scale to stand level $[1,31]$.

\subsection{Tree hydraulic conductivity}

In 1995, ten small (basal diameter $0.5 \mathrm{~cm}$ ) and two larger (basal diameter $2.5 \mathrm{~cm}$ ) branches per tree were collected from the top of the crown of five trees per stand and immediately re-cut under water. On the small branches hydraulic conductivity $\mathrm{K}_{\mathrm{h}}\left(\mathrm{kg} \mathrm{s}^{-1} \mathrm{~m} \mathrm{MPa}^{-1}\right)$ and vulnerability to embolism were measured in 2-yearold segments $5 \mathrm{~mm}$ in diameter (including bark) and $40 \mathrm{~mm}$ in length using a conductivity apparatus as described by Sperry et al. [23]. Branches were bench-top dried. Hydraulic conductance $\mathrm{K}_{\mathrm{T}}\left(\mathrm{kg} \mathrm{s}^{-1} \mathrm{MPa}^{-1}\right)$ and $\mathrm{K}_{\mathrm{h}}$ of the larger branches were measured in the field with a high-pressure flowmeter [27, 33]. We used de-ionised, de-gased, filtered $(0.2 \mu \mathrm{m}) 0.01 \mathrm{~N} \mathrm{HCl}$ and, for the segments, a pressure of $6 \mathrm{kPa}$.

\subsection{Tree water status}

From 1993 to 1995 , the water status of the stands was assessed by periodical measurements of pre-dawn water potential. Two twigs per tree from the upper crown of ten trees per stand were collected with a shotgun and the balancing pressure of two fascicles per twig was immediately measured with a pressure chamber.

\subsection{Tree canopy transpiration}

Tree canopy transpiration was estimated by sap flow measurements in 15 representative trees per stand using a constant heating method [8]. Two gauges were installed at breast height in each tree ranging from 0 to $2.1 \mathrm{~cm}$ and 2.2 to $4.4 \mathrm{~cm}$ from the cambium, respectively. Automatic readings were taken every $30 \mathrm{~s}$ and averaged over 30-min periods. Data were collected between August 1993 and November 1995.

Conductive sapwood area was measured in all 45 sample trees by computer-tomography [5, 10, 19] in collaboration with the Centre for Radiology of the PhillipsUniversity Marburg. From inventories of the study plots and the data on sapwood area in the sample trees, stand sapwood area was calculated. Stand sap flow was calculated as the product of average sap flow density and stand sapwood area. 


\subsection{Ground vegetation: species, biomass and LAI}

At each site, five to eight plots of $9 \mathrm{~m}^{2}$ were established in the summer of 1994 . The plots were divided into four quadrants to estimate cover degree of all plant species to the nearest percent. Because transpiration was not measured for mosses, their cover was estimated without differentiating for species. All plots were pooled to calculate monthly averages of cover. We followed the nomenclature of Schmeil and Fitschen [21].

In three plots $\left(0.25 \mathrm{~m}^{2}\right)$ per site all living herbaceous plants were collected in height strata of $10 \mathrm{~cm}$, dried at $80{ }^{\circ} \mathrm{C}$ and weighed. For each relevant species means of the biomass were scaled to a hectare basis. Specific leaf area for these species was estimated with an image analysis system (CUE-3 image analyser, Olympus). Using the specific leaf area and the leaf biomass the leaf area index of these species $\left(\mathrm{LAI}_{\mathrm{part}}\right.$ ) was calculated. The LAI of the herbaceous layer is the sum of the LAI $_{\text {part }}$.

\subsection{Transpiration of the ground vegetation}

Transpiration was measured monthly for species with at least $10 \%$ cover within an minimum area of $200 \mathrm{~m}^{2}$. In Rösa, these were Brachypodium sylvaticum, Calamagrostis epigeios and Rubus idaeus, in Taura Deschampsia flexuosa and in Neuglobsow Deschampsia flexuosa and Vaccinium myrtillus. In the growing season of 1995 diurnal courses were measured during periods of bright days with a climatised porometer (compact $\mathrm{CO}_{2} / \mathrm{H}_{2} \mathrm{O}$ porometer, Walz, Effeltrich). Five-minute averages of exposed leaves of one species were recorded from dawn until dusk. The daily output of transpiration of a species was scaled up to the stand level using its leaf area index $\left(\mathrm{LAI}_{\text {part }}\right)$.

Wedler [29] expected only low differences in the relationship of transpiration rates of patch types in the field layer within a week. According to this fact we assumed that the relation of the transpiration rates of different herb species to each other were nearly equal within 2 to 3 consecutive days. The measured daily transpiration of a herb species was related to the canopy transpiration on the same day. Continuously measured canopy transpiration was used as reference to calculate the total herb layer transpiration. The ratio of ground vegetation transpiration to tree transpiration was interpolated through periods without measurements and used to estimate herb layer transpiration from tree transpiration during these times.

\section{Results}

\subsection{Ground vegetation}

The vegetation of Neuglobsow was dominated by Deschampsia flexuosa (about 15-23\% from April to July) and Vaccinium myrtillus (about 8-13\% from April to July) indicating a site without major deposition. Rösa, however, was dominated by Calamagrostis epigeios (about 12-29\% from April to July) and Brachypodium sylvaticum (ranged from about 4-18\%), showing the influence of recent $\mathrm{N}$-fertilisation and Ca-deposition. The species in Taura were a mix of $\mathrm{N}$-indicators such as Calamagrostis epigeios and Rubus idaeus and acid-tolerant species such as Deschampsia flexuosa, and the latter reached cover degrees of about 44-57\% from April to July [32].

Large differences between sites were found for the LAI (table II). Rösa, because of the prevalence of wideleafed species, had two to three times the LAI of Neuglobsow.

\subsection{Needle mass and leaf area index of the trees}

Needle mass was highest in Rösa $\left(7.22 \pm 0.53 \mathrm{t} \mathrm{ha}^{-1}\right)$, intermediate in Taura $\left(5.89 \pm 0.72 \mathrm{t} \mathrm{ha}^{-1}\right)$ and lowest in Neuglobsow $\left(5.42 \pm 0.51 \mathrm{t} \mathrm{ha}^{-1}\right)$. The higher specific needle area and needle mass of Rösa resulted in the highest LAI (3.71 \pm 0.27 compared to Neuglobsow $2.38 \pm$ 0.15 and Taura $2.65 \pm 0.32$ ).

\subsection{Hydraulic conductivity}

In 2-year-old segments with an outer diameter of ca $5 \mathrm{~mm}$ and water potentials close to $0 \mathrm{MPa}$, the hydraulic conductivity $K_{h}$ was significantly higher in Neuglobsow $(P<0.013)$. Over much of the tested range of xylem water potential, $\mathrm{K}_{\mathrm{h}}$ of segments from Neuglobsow was highest, but there was no interaction effect of xylem water potential and site on $\mathrm{K}_{\mathrm{h}}$ (figure 2 ). The leaf specific conductance LSC, i.e. the hydraulic conductivity divided by the projected needle area distal to the measured segment, was $52 \%$ higher in Neuglobsow than in the other stands (significance of difference $P<0.005$ ). The Huber value (sapwood area/needle area) of segments from Rösa was significantly lower than in Neuglobsow. Since the conductivity per cross-sectional area (specific conductivity) was not significantly different (data not shown), this resulted in higher LSC in Neuglobsow over the range $2-15 \mathrm{~mm}$ xylem diameter. 
Table II. Proportional leaf area index (LAI part) of herbaceous species during the vegetation period 1995.

\begin{tabular}{|c|c|c|c|c|c|c|c|c|c|}
\hline \multirow[t]{2}{*}{ Stand } & \multirow{2}{*}{\begin{tabular}{l}
\multicolumn{1}{c}{ Herbaceous species } \\
(Species with $>10 \%$ cover. \\
at least in 1 month)
\end{tabular}} & \multicolumn{2}{|c|}{ End of April } & \multicolumn{2}{|c|}{ End of May } & \multicolumn{2}{|c|}{ End of June } & \multicolumn{2}{|c|}{ End of July } \\
\hline & & $\begin{array}{l}\text { LAI part } \\
\left(\mathrm{m}^{2} / \mathrm{m}^{-2}\right)\end{array}$ & $\begin{array}{c}\text { Portion } \\
(\%)\end{array}$ & $\begin{array}{l}\text { LAI part } \\
\left(\mathrm{m}^{2} / \mathrm{m}^{-2}\right)\end{array}$ & $\begin{array}{c}\text { Portion } \\
(\%)\end{array}$ & $\begin{array}{l}\text { LAI part } \\
\left(\mathrm{m}^{2} / \mathrm{m}^{-2}\right)\end{array}$ & $\begin{array}{c}\text { Portion } \\
(\%)\end{array}$ & $\begin{array}{l}\text { LAI part } \\
\left(\mathrm{m}^{2} / \mathrm{m}^{-2}\right)\end{array}$ & $\begin{array}{c}\text { Portion } \\
(\%)\end{array}$ \\
\hline Rösa & $\begin{array}{l}\text { Calamagrostis epigeios } \\
\text { Brachypodium sylvaticum } \\
\text { Rubus idaeus } \\
\text { Rubus fabrimontanus } \\
\text { Deschampsia flexuosa } \\
\text { Total }\end{array}$ & $\begin{array}{l}0.26 \\
0.16 \\
0.00 \\
0.06 \\
0.00 \\
0.48\end{array}$ & $\begin{array}{c}54 \\
33 \\
0 \\
13 \\
0\end{array}$ & $\begin{array}{l}0.96 \\
1.03 \\
0.07 \\
0.07 \\
0.02 \\
2.15\end{array}$ & $\begin{array}{c}45 \\
48 \\
3 \\
3 \\
1\end{array}$ & $\begin{array}{l}1.02 \\
0.81 \\
0.15 \\
0.10 \\
0.01 \\
2.09\end{array}$ & $\begin{array}{c}49 \\
39 \\
7 \\
5 \\
0\end{array}$ & $\begin{array}{l}0.62 \\
1.42 \\
0.14 \\
0.11 \\
0.16 \\
2.45\end{array}$ & $\begin{array}{c}25 \\
58 \\
6 \\
4 \\
7\end{array}$ \\
\hline Taura & $\begin{array}{l}\text { Deschampsia flexuosa } \\
\text { Total }\end{array}$ & $\begin{array}{l}0.71 \\
0.71\end{array}$ & 100 & $\begin{array}{l}1.40 \\
1.40\end{array}$ & 100 & $\begin{array}{l}1.65 \\
1.65\end{array}$ & 100 & $\begin{array}{l}1.42 \\
1.42\end{array}$ & 100 \\
\hline Neuglobsow & $\begin{array}{l}\text { Deschampsia flexuosa } \\
\text { Vaccinium myrtillus } \\
\text { Total }\end{array}$ & $\begin{array}{l}0.51 \\
0.07 \\
0.58\end{array}$ & $\begin{array}{l}88 \\
12\end{array}$ & $\begin{array}{l}0.46 \\
0.05 \\
0.51\end{array}$ & $\begin{array}{c}91 \\
9\end{array}$ & $\begin{array}{l}0.60 \\
0.16 \\
0.76\end{array}$ & $\begin{array}{l}79 \\
21\end{array}$ & $\begin{array}{l}0.78 \\
0.23 \\
1.01\end{array}$ & $\begin{array}{l}77 \\
23\end{array}$ \\
\hline
\end{tabular}

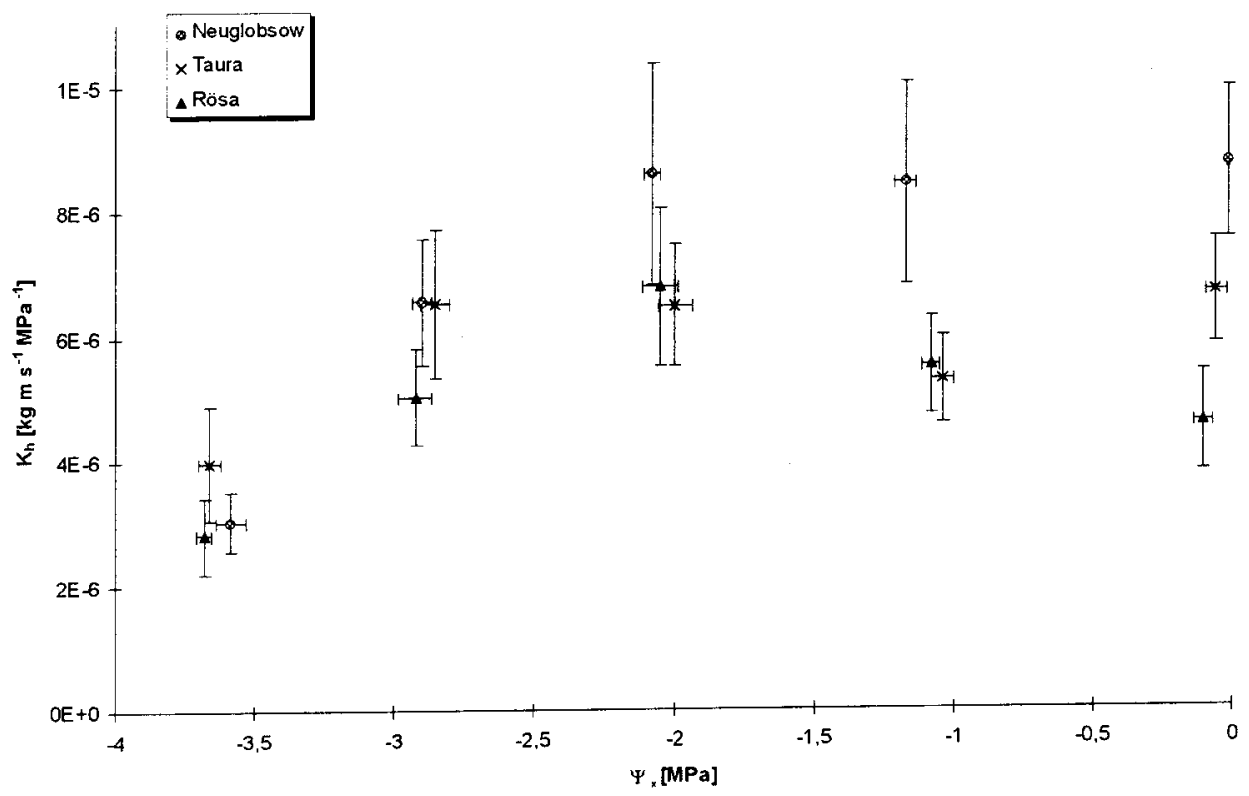

Figure 2. Decrease in xylem hydraulic conductivity $\mathrm{K}_{\mathrm{h}}$ of 2-year-old twigs with xylem water potential $\psi_{\mathrm{x}}$. Bars indicate one standard deviation.

For stems, the leaf area to sapwood area ratio at breast height $(1.3 \mathrm{~m})$ for the three stands was highest in Rösa and lowest in Neuglobsow (table III).

\subsection{Water status of the trees}

Pre-dawn water potentials differed substantially between 1994 and 1995 (figure 3). During a long period of drought in 1994 pre-dawn water potential fell from above $-0.5 \mathrm{MPa}$ in spring to below $-1.0 \mathrm{MPa}$ at the end of July. In Neuglobsow trees reached the lowest needle water potentials with single trees as low as $-2.6 \mathrm{MPa}$, on average $-1.65 \pm 0.24 \mathrm{MPa}$ as compared to Rösa with $-1.16 \pm 0.21 \mathrm{MPa}$. In 1995 , pre-dawn water potentials never fell below $-1.0 \mathrm{MPa}$. 
Table III. Parameters of hydraulic architecture.

\begin{tabular}{lcccc}
\hline & Units & Rösa & Taura & Neuglobsow \\
\hline $\mathrm{K}_{\mathrm{h}}$ & $\left(10^{-6} \mathrm{~kg} \mathrm{~m} \mathrm{~s}^{-1} \mathrm{MPa}^{-1}\right)$ & $5.29 \pm 0.51$ & $5.31 \pm 0.64$ & $8.4 \pm 1.2$ \\
$\mathrm{HV}$ (twigs) & $\left(10^{-4} \mathrm{~cm}^{2} \mathrm{~cm}^{-2}\right)$ & $2.41 \pm 0.09$ & $2.61 \pm 0.11$ & $3.35 \pm 0.16$ \\
$\mathrm{HV}$ (tree) & $\left(10^{-4} \mathrm{~cm}^{2} / \mathrm{cm}^{-2}\right)$ & 4.8 & 6.1 & 9.5 \\
Leaf area per sapwood & $\left(\mathrm{cm}^{2} / \mathrm{cm}^{2}\right)$ & $2071 \pm 153$ & $1642 \pm 199$ & $1058 \pm 100$ \\
area $\left(\mathrm{HV}^{-1}\right)$ (tree) & & & & \\
\hline
\end{tabular}

$\mathrm{K}_{\mathrm{h}}$, hydraulic conductivity; HV, Huber value.
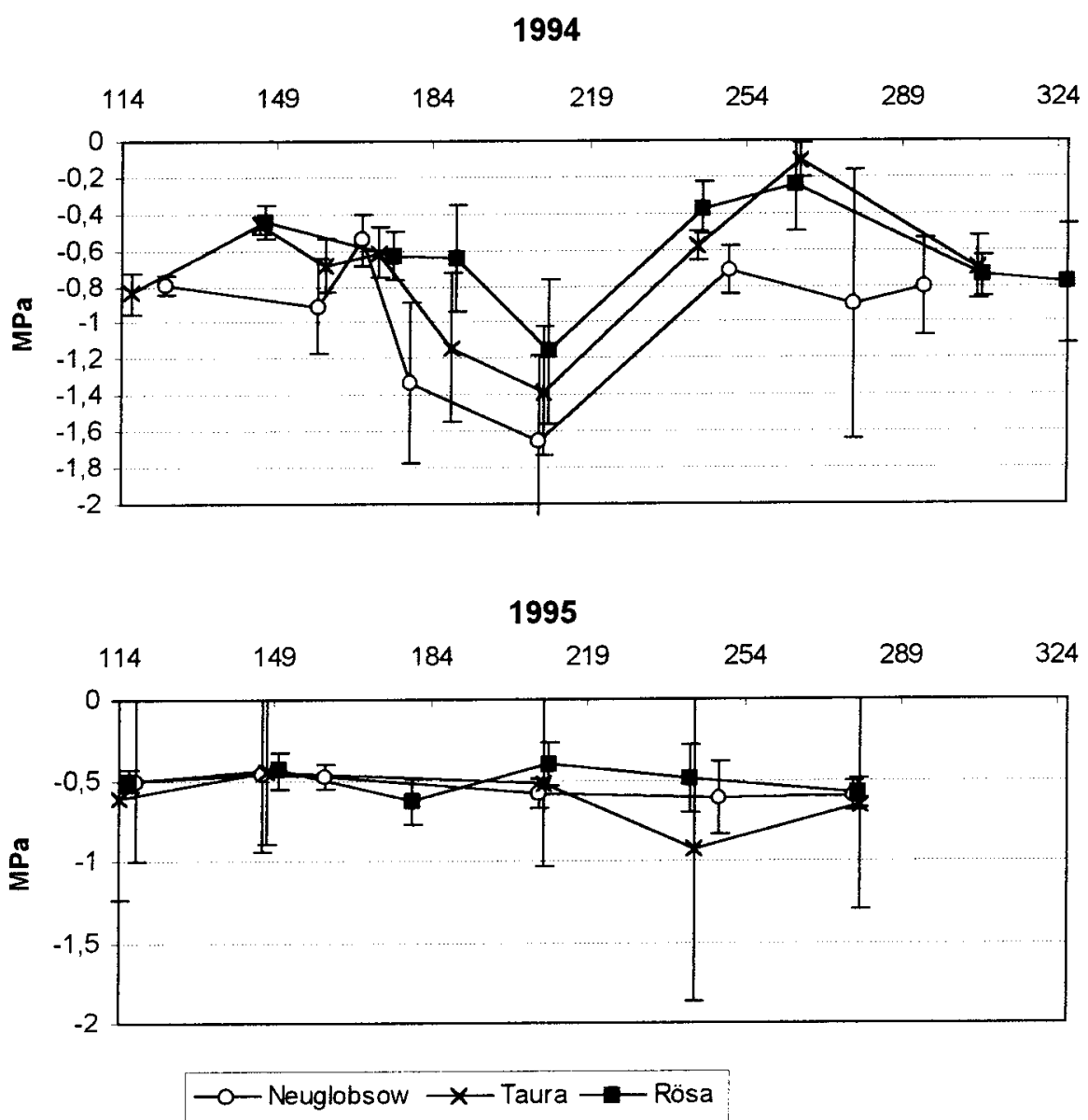

Figure 3. Pre-dawn water potential (MPa) for 1994 and 1995.

\subsection{Tree canopy transpiration}

The ratio of sap flow densities of inner and outer sapwood differed significantly between the stands (table $I V)$. In Rösa the mean flow density in the outer sapwood was higher than at the other sites, but decreased much more steeply towards the heartwood than in Taura and Neuglobsow. Over 4 weeks of comparable climatic con- ditions, the ratio of sap flow densities of inner and outer sapwood was 0.88 in Neuglobsow, but 0.40 in Rösa. In Taura, we found a ratio of 0.63 (all differences significant at $P<0.001$ ). For the entire growing season of 1994, sapflow densities at the outer sensors in Rösa were significantly higher than in Neuglobsow, but significantly lower at the inner sensors. On average, sap flow per tree in Rösa was $90 \%$ of that in Neuglobsow. 
Table IV. Mean sap flow density $\left(\mathrm{kg} \mathrm{dm}^{-2} \mathrm{~d}^{-1}\right)$ in June 1994.

\begin{tabular}{lccc}
\hline & Rösa & Taura & Neuglobsow \\
\hline Outer sensor & $4.91 \pm 0.04$ & $3.68 \pm 0.08$ & $4.68 \pm 0.08$ \\
Inner sensor & $1.96 \pm 0.09$ & $2.32 \pm 0.06$ & $4.14 \pm 0.08$
\end{tabular}

The ratio of sap flow densities of inner and outer sapwood, however, were not constant, but changed from year to year and rose close to unity in periods with low flow rates, e.g. at the beginning and the end of the growing season.
Daily tree canopy transpiration per ground area for 1994 and 1995 is shown in figure 4. On fine days, transpiration reached approximately $1 \mathrm{~mm} \mathrm{~d}^{-1}$, in Neuglobsow up to $1.5 \mathrm{~mm} \mathrm{~d}^{-1}$. Because of declining soil water availability, transpiration in Neuglobsow fell to less than one third from mid July to mid August 1994, in spite of fairly constant climatic conditions. Tree canopy transpiration during the growing season of 1994 (April to September) was $106 \mathrm{~mm}$ in Rösa, $82 \mathrm{~mm}$ in Taura and $113 \mathrm{~mm}$ in Neuglobsow. In 1995, the values were Rösa 94, Taura 90 and Neuglobsow $122 \mathrm{~mm}$.
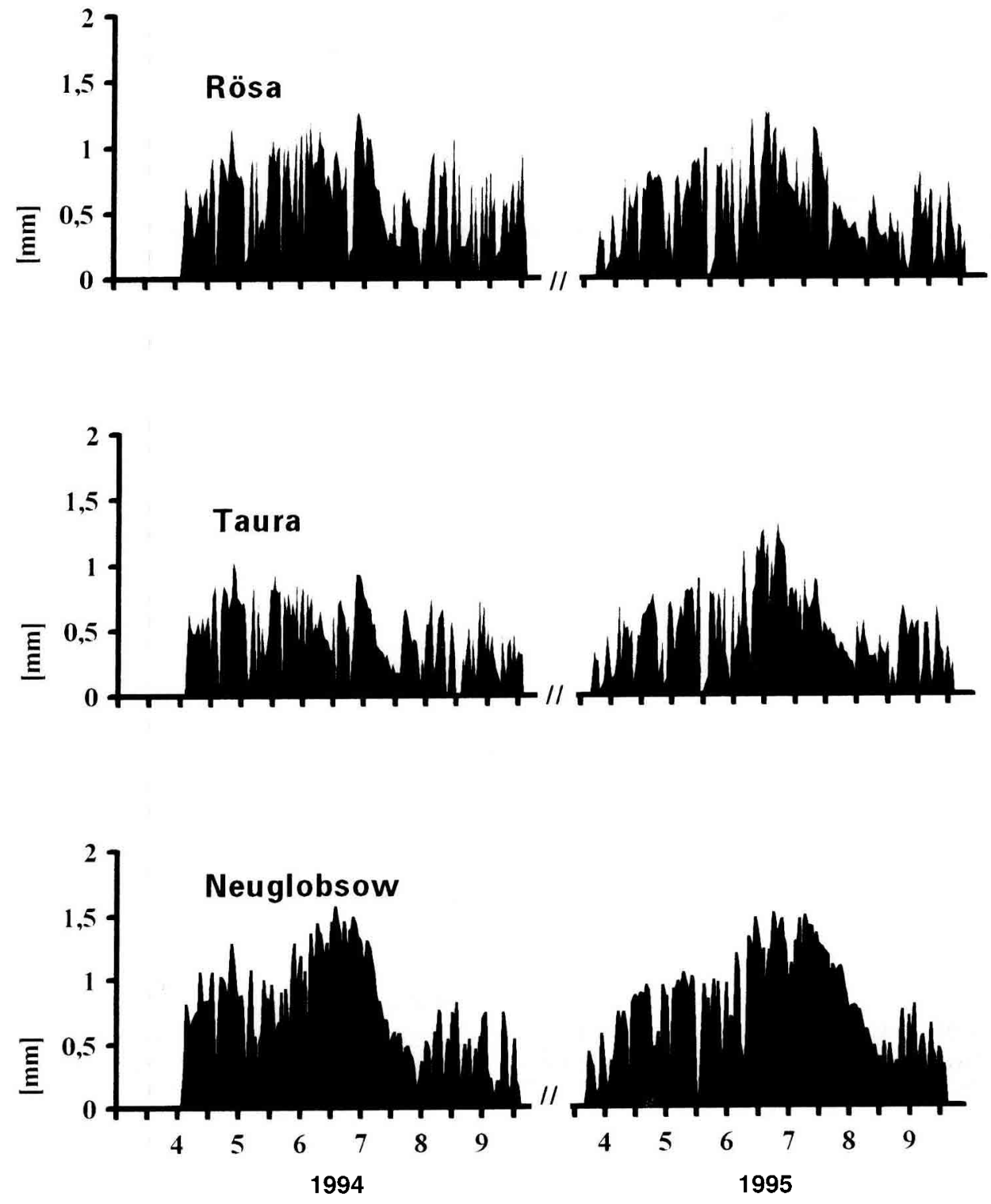

Figure 4. Daily tree canopy transpiration $[\mathrm{mm}$ $\left.\mathrm{d}^{-1}\right]$ of the pines during the vegetation periods 1994 and 1995. 
Transpiration per needle area (stand transpiration per hectare divided by projected needle area per hectare) was lower for the nitrogen-fertilised and polluted stands in Rösa and Taura in all 3 years. For days with non-limiting soil water availability, i.e. soil water potential above $-100 \mathrm{hPa}$, there was a highly significant difference in transpiration per needle area between these stands (figure 5).

\subsection{Contribution of the ground vegetation to stand transpiration}

During fine summer days, ground vegetation transpiration exceeded tree transpiration. In Neuglobsow, where tree transpiration rates were highest, ground vegetation transpiration (excluding mosses) reached half the tree transpiration (table $V$ ). Comparing the results of tables II and $V$, the relative contribution of a species to stand transpiration is mainly controlled by leaf area index and specific transpiration rates. While in July the LAI of Rubus idaeus did not exceed $6 \%$ of the total herb layer in Rösa, this species contributed $12 \%$ to herb transpiration. Vaccinium myrtillus, however, transpired less than $18 \%$ of the herb layer, although its partial LAI was $23 \%$.

Stand transpiration is the sum of field layer transpiration and tree canopy transpiration. Since ground vegetation transpiration data were only available for some days, stand transpiration estimates have to be rather rough. For the growing season of 1995, these are $185 \mathrm{~mm}$ in Rösa, $173 \mathrm{~mm}$ in Taura and $184 \mathrm{~mm}$ in Neuglobsow.

\section{Discussion}

The cumulated LAI of the herb layer in Taura is similar to 1.54 reported by Wedler et al. [29] for a 30-yearold pine stand at Hartheim in the upper Rhine valley. The LAI of the herb layer at Rösa was higher because of the dominance of the wide-leafed species Calamagrostis epigeios and Brachypodium sylvaticum. The absence of these species is the reason for the low LAI in Neuglobsow, although the leaf area of moss species was not taken into account. During summer the transpiration of the herb layer of up to $50 \%$ of the stand transpiration was higher than expected. Granier et al. [9], from sap flow and eddy correlation measurements at Hartheim, estimated a herb layer contribution to total vapour flux of $26 \%$. A contribution of the herb layer to stand transpiration comparable to our results was found by Tan and Black [25], Black [3], Roberts et al. [18] and Spittlehouse [24]. Due to the low number of days measured at each site and the variable weather conditions during field works our data can only be rough estimates. However, investigations in a Scots pine ecosystem in the upper Rhine valley have shown that the relationships among transpiration rates of different patch types in the field layer do not change significantly within a week [29]. Additionally, the counteracting effects of measuring exposed, leafy plant parts and excluding plant stems in the procedure of up-scaling are not known. While the first leads to an overestimation of transpiration, the exclusion of plant stems may cause an underestimation.

Table V. Contribution of the species to stand transpiration.

\begin{tabular}{|c|c|c|c|c|c|}
\hline \multirow[t]{2}{*}{ Stand } & \multirow{2}{*}{$\begin{array}{l}\text { Species } \\
\text { (measurement of transpiration in the herb layer } \\
\text { concerning only species with at least. } 10 \% \text { cover) }\end{array}$} & \multicolumn{4}{|c|}{ Contribution to stand transpiration $(\%)$} \\
\hline & & $\begin{array}{c}\text { End of } \\
\text { April }\end{array}$ & $\begin{array}{c}\text { End of } \\
\text { May }\end{array}$ & $\begin{array}{l}\text { End of } \\
\text { June }\end{array}$ & $\begin{array}{c}\text { End of } \\
\text { July }\end{array}$ \\
\hline \multirow[t]{4}{*}{ Rösa } & Pinus sylvestris & 72 & 44 & 52 & 50 \\
\hline & Brachypodium sylvaticum & 7 & 11 & 11 & 18 \\
\hline & Calamagrostis epigeios & 20 & 41 & 31 & 18 \\
\hline & Rubus fabrimontanus ** & 1 & 2 & 3 & 5 \\
\hline \multirow[t]{2}{*}{ Taura } & Pinus sylvestris & 67 & 57 & 49 & 45 \\
\hline & Deschampsia flexuosa & 33 & 43 & 51 & 55 \\
\hline Neuglobsow & Pinus sylvestris & 74 & 76 & 58 & 66 \\
\hline
\end{tabular}

\footnotetext{
* Data were scaled up using the transpiration of this species in Taura.

** Data were scaled up using the transpiration values from Rubus idaeus.
} 


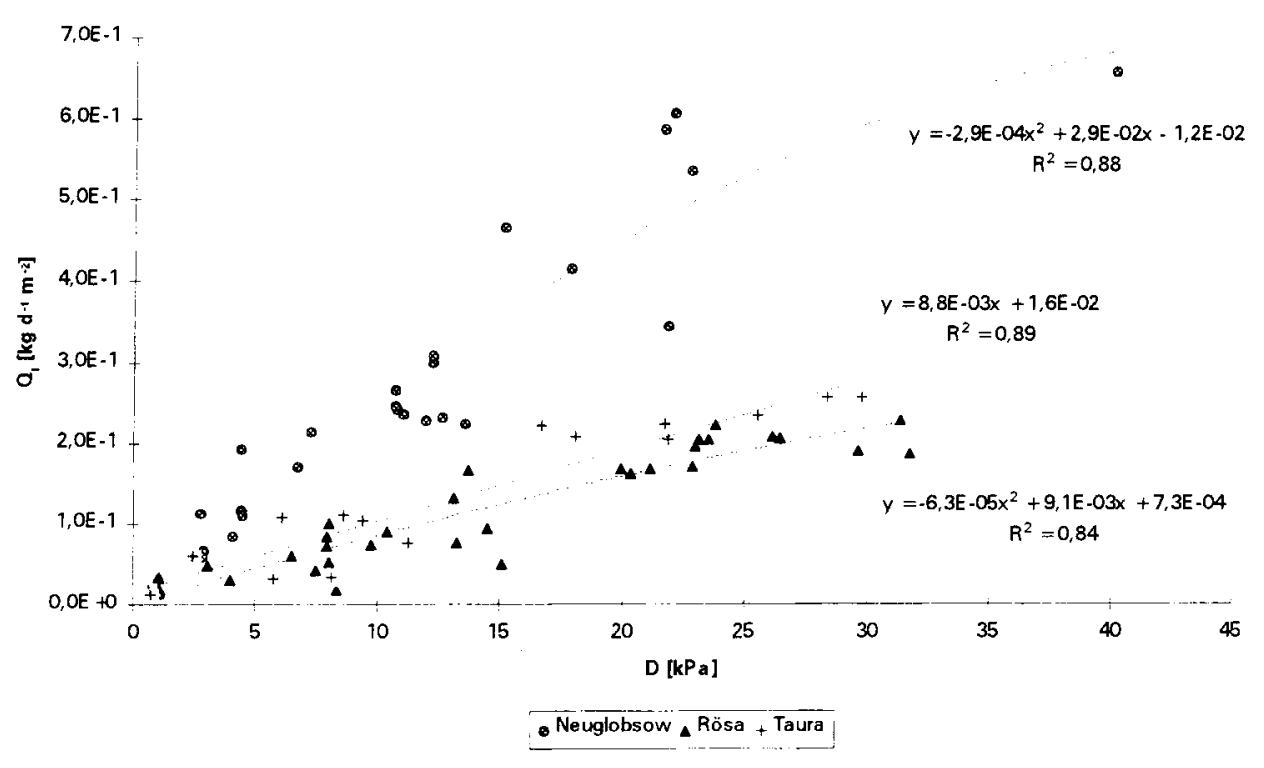

Figure 5. Transpiration rate for days with soil water potentials above $-100 \mathrm{hPa}$. $Q_{1}$ is transpiration in $\mathrm{kg} \mathrm{m}^{-2}$ $\mathrm{d}^{-1}$, D is cumulated daily vapour pressure deficit.
The leaf area indices of the tree canopies are significantly different because of the differences in needle biomass and specific leaf area. While potential evapotranspiration at the three sites was comparable, soil water availability was highest at Rösa with $150 \mathrm{~mm}$ as compared to $100 \mathrm{~mm}$ extractable soil water in the upper $50 \mathrm{~cm}$ at Neuglobsow [30]. Nevertheless, a lower transpiration rate on a needle area basis caused stand canopy transpiration in Rösa to be lower than in Neuglobsow, despite the higher LAI of pine in Rösa. The largest differences between stands occurred during periods of drought. A reason might be the lower leaf specific conductivity of the xylem. Our estimates of hydraulic conductivity of whole trees, stems, and branches indicate a lower conductivity of the pine trees in Rösa than in Neuglobsow. The leaf area to sapwood area ratio found in Rösa $\left(2078 \mathrm{~cm}^{2} \mathrm{~cm}^{-2}\right)$ was twice that of Neuglobsow and highly compared to other studies. Van Hees and Bartelink [28] report $900-1300 \mathrm{~cm}^{2} \mathrm{~cm}^{-2}$ and Mencuccini and Grace [17] found $800-1700 \mathrm{~cm}^{2} \mathrm{~cm}^{-2}$ for Scots pine. Models [13, 26] and field experiments [4, 16] show that stomatal regulation can play an important role in controlling the development of xylem embolism. Because of their lower conductance, trees in Rösa would have to develop a much steeper water potential gradient, with the risk of xylem dysfunction and decreasing conductivity, if they were to sustain a transpiration rate as high as the trees in Neuglobsow [13, 23, 26, 34]. However, xylem water potentials of the stands were always in the same range, with Neuglobsow at the lower end. Transpiration rate might be adjusted to tree hydraulic conductance in a way that avoids the develop- ment of water potentials that cause xylem embolism. The drought stress developed during drought in Rösa was not higher than in Neuglobsow. This, together with the assumption that tree transpiration rates in Rösa were more limited by hydraulic architecture than in Neuglobsow, leads us to the conclusion that there was no severe competition of ground vegetation. Rather, the herbaceous species used the water left by the trees. Therefore, stand transpiration for all three stands is of the same magnitude, although there are large differences in species composition and stand structure.

Acknowledgements: This study was funded by the German ministry of education and science. We thank Mel Tyree for giving Steffen Rust the chance to study their methods at the Proctor Maple Research Station and André Granier for critical comments on this paper. We thank our technicians Bodo Grossmann and Lothar Löwe.

\section{References}

[1] Albrektson A., Sapwood basal area and needle mass of Scots pine (Pinus sylvestris L.) trees in Central Sweden, Forestry 57 (1984) 36-43.

[2] Bergmann J.H., Das Sandrohr (Calamagrostis epigeios (L.) Roth). Forschungsbericht, Zeneca Agro, Frankfurt/M, 1993.

[3] Black T.A., Tan C.S., Nnyamah J.U., Transpiration rate of Douglas fir trees in thinned and unthinned stands, Can. J. Soil. Sci. 60 (1980) 625-631. 
[4] Cochard H., Breda N., Granier A., Whole tree hydraulic conductance and water loss regulation in Quercus during drought: evidence of stomatal control of embolism?, Ann. Sci. For. 53 (1996) 197-206.

[5] Edwards W.R.N., Jarvis P.G., A method for measuring radial differences in water content of intact tree stems by attenuation of gamma radiation, Plant Cell Environ. 6 (1983) 255-260.

[6] Ellenberg H., Vegetation Mitteleuropas mit den Alpen, Ulmer, Stuttgart, 1996.

[7] Ende H.P., Gluch W., Hüttl R.F., Ernährungskundliche und morphologische Untersuchungen im Kronenraum von Pinus sylvestris L., Hüttl R.F., Bellmann K., Seiler W. (Eds.), in: Atmosphärensanierung und Waldökosysteme, Blottner, Taunusstein, 1995, pp. 112-128.

[8] Granier A., Une nouvelle méthode pour la mesure du flux de sève brute dans le tronc des arbres, Ann. Sci. For. 42 (1985) 193-200.

[9] Granier A., Biron P., Köstner B., Gay L.W., Najjar G., Comparison of xylem sap flow and water vapour flux at the stand level and derivation of canopy conductance of Scots pine, Theor. Appl. Climat. 53 (1996) 115-122.

[10] Habermehl A., Ridder H.-W., Schmidt S., Mobiles Computer-Tomographie Gerät zur Untersuchung ortsfester Objekte, Atomenergie, Kerntechnik 48 (1986) 94-99.

[11] Hofmann G., Der Wald. Sonderheft WaldökosystemKatalog, Deutscher Landwirtschaftsverlag, Berlin, 1994.

[12] Hüttl R.F., Bellmann K., Seiler W., Einleitung und Hintergrund zum wissenschaftlichen Begleitprogramm SANA, in: Hüttl R.F., Bellmann K., Seiler W. (Eds.), Atmoshärensanierung und Waldökosysteme, Blottner, Taunusstein, 1995, pp. 10-18.

[13] Jones H.G., Sutherland R.A., Stomatal control of xylem embolism, Plant Cell. Environ. 14 (1991) 607-612.

[14] Kaibyainen L.K., Khari P., Sazonova T., Myakelya A., Balance of water transport in Pinus sylvestris L., III. Conducting xylem area and needle amount, Lesowedenje 1 (1986) 31-37.

[15] Kopp D., Vegetationsveränderungen auf Waldstandorten des Tieflandes durch Immission basischer Flugaschen und Zementstäube, Archiv Naturschutz und Landschaftsforschung (Berlin) 26 (1986) 105-115.

[16] Lu P., Biron P., Granier A., Cochard H., Water relations of adult Norway spruce (Picea abies (L.) Karst.) under soil drought in the Vosges mountains: whole tree hydraulic conductance, xylem embolism and water loss regulation, Ann. Sci. For. 53 (1996) 113-121.

[17] Mencuccini M., Grace J., Climate influences the leaf area / sapwood area ratio in Scots pine. Tree Physiol. 15 (1995) $1-10$.

[18] Roberts J., Pymar C.F., Wallace J.S., Pitman R.M., Seasonal changes in leaf area, stomatal and canopy conductance and transpiration from bracken below a forest canopy, $\mathrm{J}$. Appl. Ecol. 17 (1980) 409-422.

[19] Rust S., Lüttschwager D., Hüttl R.F., Transpiration and hydraulic conductivity in three Scots pine (Pinus sylvestris L.) stands with different air pollution histories, Water Air Soil Pol, 85 (1995) 1677-1682.

[20] Schaaf W., Weisdorfer M., Hüttl R.F., Soil solution chemistry and element budgets of three Scots pine stand along a deposition gradient in northeastern Germany, Water Air Soil Pol. 85 (1995) 1197-1202.

[21] Schmeil O., Fitschen J., Flora von Deutschland und angrenzender Länder. 89. Aufl., Quelle und Meyer, Heidelberg/Wiesbaden, 1993.

[22] Schulz H., Huhn G., Härtling S., Responses of sulphurand nitrogen-containing compounds in Scots pine needles along a deposition gradient in eastern Germany, in: Hüttl R.F. et al. (Eds.), Forest Ecosystems and Atmospherical Deposition Changes, Kluwer Academic Publishers, 1999 (in press).

[23] Sperry J.S., Donnelly J.R., Tyree M.T., A method for measuring hydraulic conductivity and embolism in $x y l \mathrm{~cm}$, Plant Cell Environ. 11 (1988) 35-40.

[24] Spittlehouse D.L., Impact of competing vegetation on site water balance, in: FRDA-Report, Victoria, BC, Forestry Canada, May 1988 (026), pp. 28-30.

[25] Tan C.S., Black T.A., Factors affecting the canopy resistance of a Douglas fir forest, Boundary Layer Meteorol. 10 (1976) 475-488.

[26] Tyree M.T., Sperry J.S., Do woody plants operate near the point of catastrophic xylem dysfunction caused by dynamic water stress? Answers from a model, Plant Physiol. 88 (1988) 574-580.

[27] Tyree M.T., Patino S., Bennink J., Alexander J., Dynamic measurements of root hydraulic conductance using a high-pressure flowmeter in the laboratory and field, J. Exp. Bot. 46 (1995) 83-94.

[28] Van Hees A.F.M., Bartelink H.H., Needle area relationships of Scots pine in the Netherlands, For. Ecol. Manage. 58 (1993) 19-31.

[29] Wedler M., Heindl B., Hahn S., Köstner B., Bernhofer C., Tenhunen J.D., Model-based estimates of water loss from 'patches' of the understorcy mosaic of the Hartheim Scots pine plantation, Theor. Appl. Climat. 53 (1996) 135-144.

[30] Weisdorfer M., Schaaf W., Blechschmidt R., Schütze J., Hüttl R.F., Soil chemical response to drastical reductions in deposition and its effects on the element budgets of three Scots pine ecosystems with different pollution history in northeastern Germany, in: Hüttl R.F. et al. (Eds.), Forest Ecosystems and Atmospherical Deposition Changes, Kluwer Academic Publishers, 1999 (in press).

[31] Whitehead D., The estimation of foliage area from sapwood basal area in Scots pine, Forestry 51 (1978) 137-149.

[32] Wulf M., Lüttschwager D., Forkert J., Hüttl R.F., Untersuchungen zum Deckungs- und Transpirationsgrad ausgewählter Pflanzenarten der Krautschicht in Kiefernbeständen, J. Appl. Bot. 70 (1996) 165-171.

[33] Yang S., Tyree M.T., Hydraulic resistance in Acer saccharum shoots and its influence on leaf water potential and transpiration, Tree Physiol. 12 (1993) 31-42.

[34] Zimmermann M.H., Xylem Structure and the Ascent of Sap, Springer, Berlin, 1983. 